\title{
BRPKM
}

Buletin Riset Psikologi dan Kesehatan Mental

http://e-journal.unair.ac.id/index.php/BRPKM

e-ISSN: 2776-1851

ARTIKEL PENELITIAN

\section{Dinamika Konsep Diri Remaja dengan Orang Tua Bercerai Berdasarkan Usia Remaja Ketika Perceraian Terjadi}

\author{
NI LUH AYU W. S. K. \& ARYANI TRI WRASTARI* \\ Fakultas Psikologi Universitas Airlangga
}

\begin{abstract}
ABSTRAK
Peristiwa perceraian tentu tidak hanya mempengaruhi hubungan suami istri, tetapi juga membawa dampak yang mendalam bagi anak termasuk pada konsep dirinya. Menurut Fitts, konstruk konsep diri terbagi dalam dua dimensi yaitu dimensi internal dan eksternal berikut masing-masing subdimensinya. Penelitian ini bertujuan untuk mengetahui dinamika konsep diri berdasarkan teori milik Fitts pada remaja yang memiliki orang tua bercerai berdasarkan usia remaja ketika perceraian orang tua terjadi. Penelitian ini menggunakan desain penelitian kualitatif. Hasil penelitian ini menunjukkan bahwa kelompok yang mengalami perceraian orang tua saat usia anak-anak dan kelompok yang mengalami perceraian orang tua saat usia remaja memiliki dinamika antar dimensi dan subdimensi konsep diri yang serupa. Diri identitas mempengaruhi diri pelaku kedua kelompok usia. Diri pribadi mempengaruhi diri pelaku pada kelompok usia yang mengalami percerceraian orang tua di usia anak-anak, sementara diri pribadi mempengaruhi diri sosial pada kelompok usia yang mengalami perceraian orang tua di usia remaja.
\end{abstract}

Kata kunci: konsep diri, orang tua bercerai, remaja

\begin{abstract}
Divorce phenomenon not only affect the husband-and-wife relationship, but also have a deep impact on children, including their self-concept. According to Fitts, construct of self-concept is divided into two dimensions, namely internal and external dimensions and their respective sub-dimensions. This study aims to determine the dynamics of self-concept based on Fitts' theory in adolescents whose parents divorced based on their adolescent age when their parents divorced. This study uses qualitative research design. The results of this study indicate that group that experienced parental divorce as children and group that experienced parental divorce during their adolescents' years had similar dynamics between dimensions and sub-dimensions of self-concept. Self-identity affects the perpetrator's self in both age groups. The personal self affects behavioral self in age group who experienced parental divorce at the age of children, while personal self affects social self in age group who experienced parental divorce in their teens.
\end{abstract}

Keywords: adolescents, parents divorced, self concept

Buletin Penelitian Psikologi dan Kesehatan Mental (BRPKM), 2021, Vol. 1(2), 1253-1262

*Alamat korespondensi: Fakultas Psikologi Universitas Airlangga, Kampus B Universitas Airlangga Jalan

Airlangga 4-6 Surabaya 60286. Surel: aryani.wrastari@psikologi.unair.ac.id

Naskah ini merupakan naskah dengan akses terbuka dibawah ketentuan the Creative Common Attribution License (CC-BY-4.0) (http://creativecommons.org/licenses/by/4.0), sehingga penggunaan, distribusi, reproduksi dalam media apapun atas artikel ini tidak dibatasi, selama sumber aslinya disitir dengan baik. 


\section{PENDAHULUAN}

Perceraian merupakan fenomena yang angkanya setiap tahun selalu mengalami peningkatan, bahkan dalam beberapa tahun terakhir Badan Pusat Statistik (BPS) mencatat peningkatan yang signifikan. BPS mencatat terjadi kasus perceraian yang terjadi pada tahun 2015 sebanyak 353.843 kasus. Lalu pada tahun 2016, kasus perceraian mengalami kenaikan menjadi 365.654 kasus. Begitu pula pada tahun 2017, kasus perceraian naik menjadi 374.516 kasus, dan pada tahun 2018, kasus perceraian mengalami kenaikan sebesar 9\% sehingga menjadi 408.202 kasus (Jayani, 2019). Sayangnya data dua tahun terakhir, yaitu tahun 2019 dan 2020 sulit didapatkan, namun pada siaran pers yang dilakukan oleh Kamaruddin Amin, Dirjen Bimas Islam Kementerian Agama, tercatat bahwa perbandingan angka pernikahan dan perceraian sebesar lima banding satu. Ini adalah angka yang memprihatinkan karena perceraian akan selalu menimbulkan permasalahan sosial yang baru. Peristiwa perceraian tentu tidak hanya memengaruhi hubungan suami istri, namun juga akan membawa dampak yang mendalam bagi anak-anak. Menurut penelitian milik (Ellison dkk., 2011), anak-anak dari keluarga utuh akan cenderung mengalami optimalisasi perkembangan yang lebih baik daripada di keluarga yang mengalami perceraian. Hal ini senada dengan berbagai temuan lain yang juga menjelaskan bahwa anak-anak dari keluarga yang bercerai dapat mengalami trauma yang cukup berat, merespon konflik orang tua dengan emosi yang negatif seperti ketakutan, kecemasan, dan stres, dan biasanya mengalami kerenggangan relasi dengan orang tua ketika anak telah dewasa (Ellison dkk., 2011; Kelly \& Emery, 2003).

Selain itu, ada kecenderungan perilaku negatif yang ditimbulkan oleh anak dari keluarga yang bercerai, seperti terlibat dalam pergaulan yang kurang baik, bermasalah dalam penyesuaian diri, cenderung berperilaku agresif, memiliki masalah internalisasi perilaku, penyalahgunaan narkoba, bermasalah dalam kinerja akademik, serta lebih banyak kesulitan dalam hubungan romantis yang akan dijalani nanti sebagai orang dewasa bila dibandingkan dengan anak-anak dari keluarga yang utuh (Ellison dkk., 2011; Hamama \& Ronen-Shenhav, 2012; Kelly \& Emery, 2003; Orgilés dkk., 2012). Dari hasil penelitianpenelitian di atas, dapat disimpulkan bahwa anak akan menjadi pihak yang lebih sering dirugikan akibat perceraian orang tua.

Selain dampak-dampak yang sudah dijelaskan di atas, perceraian orang tua juga ikut mempengaruhi aspek well-being anak. Amato (2001 dalam Ellison dkk., 2011) menjelaskan bahwa anak-anak dari keluarga yang bercerai biasanya mendapat nilai yang lebih rendah pada berbagai indikator kesejahteraan psikologis, interpersonal, dan sosial ekonomi. Anak-anak dari keluarga bercerai cenderung mendapat skor well-being yang lebih rendah dibanding anak-anak dari keluarga yang tidak bercerai, terutama pada poin kesejahteraan psikologis, konsep diri, kesejahteraan sosial, dan kualitas hubungan keluarga. Beberapa penelitian juga menunjukkan bahwa anak-anak dengan orang tua yang bercerai memiliki skor konsep diri yang jauh lebih rendah (Amato, 1994; Hamama \& Ronen-Shenhav, 2012; Orgilés dkk., 2012). Hal ini disebabkan karena konsep diri dapat terpengaruh ketika anak-anak dipaksa untuk beradaptasi dengan perubahan atau kondisi kehidupan yang negatif di lingkungan sosial mereka, seperti berbagai kesulitan pribadi maupun keluarga dan perceraian atau perpisahan orang tua (Turner dkk., 2010) .

Menurut Fitts (1971, dalam Agustiani, 2009) konsep diri adalah gambaran yang dimiliki seseorang tentang dirinya, yang dibentuk melalui pengalaman-pengalaman yang diperoleh dari interaksi dengan lingkungan. Fitts membagi konsep diri kedalam dua dimensi yaitu dimensi internal dan eksternal, dimensi ini kemudian terbagi ke dalam beberapa subdimensi. Dimensi internal memiliki tiga subdimensi yaitu, diri identitas, diri pelaku, dan diri penilai. Sedangkan dimensi eksternal memiliki lima 
subdimensi yaitu, diri fisik, diri etik-moral, diri pribadi, diri keluarga, dan diri sosial (Fitts, 1971 dalam Agustiani, 2009).

Konsep diri merupakan sesuatu yang terus berkembang dan bukanlah sesuatu yang sudah ada ketika seorang individu lahir (Agustiani, 2009; Kaur dkk., 2009). Dari berbagai fase perkembangan lainnya, diketahui bahwa remaja adalah yang paling sering diteliti oleh para peneliti terkait konsep diri (Wylie, 1974 dalam Dusek dkk., 1981). Hal ini dikarenakan masa remaja dianggap sebagai fase perkembangan dan perubahan yang cepat dan dramatis, bahkan juga fase pemberontakan (Gunarsa, S. D. \& Gunarsa, 2008). Pada masa ini, seseorang tumbuh menjadi individu yang sadar akan dirinya sendiri dan mulai melakukan penilaian terhadap dirinya.(Gunarsa \& Gunarsa, 2008).Hal ini menandakan bahwa pada usia remaja, individu mulai membentuk dan memiliki konsep diri yang lebih akurat daripada masa-masa sebelumnya (Papalia, 2004 dalam Respati dkk., 2006). Masa remaja adalah periode kunci dalam melakukan pencarian "diri" dan merupakan tugas perkembangan yang inti bagi seseorang (Erikson, 1968 dalam Crocetti, E. \& Van Dijk, 2016). Menurut teori Psikososial milik Erikson selama masa remaja, individu menghadapi tugas perkembangan identity versus identity confusion yaitu untuk menemukan siapa diri mereka dan ke mana mereka akan pergi dalam hidup (Santrock, 2014).

Salah satu faktor utama yang membentuk konsep diri remaja adalah lingkungan dan pengalaman keluarga (Crocetti, E. \& Van Dijk, 2016; Kaur dkk., 2009; Respati dkk., 2006). Individu membentuk konsep diri mereka dalam interaksinya dengan orang lain yang dekat dengan mereka (significant others), termasuk dengan orang tuanya (Cooley, 1908 dalam Crocetti, E. \& Van Dijk, 2016). Sejalan dengan itu, menurut Kaur dkk. (2009) akar konsep diri pada anak atau remaja terletak pada pengalaman keluarga. Oleh karena itu, interaksi orang tua dan anak merupakan faktor penting dalam pembentukan konsep diri anak (Malik, 2003 dalam Respati dkk., 2006).

Pandangan individu tentang diri sendiri merupakan cermin langsung dari apa yang dinilai dan dari cara anak diperlakukan oleh anggota keluarga lainnya. Sehingga dapat dikatakan bahwa ketika seseorang diperlakukan dan dinilai baik oleh anggota keluarganya, maka ia cenderung akan memandang dirinya menjadi lebih positif (Respati dkk., 2006). Terbentuknya konsep diri yang positif ini menjadi penting karena akan mempengaruhi remaja dalam berinteraksi dengan lingkungan. Remaja yang memiliki konsep diri positif akan tampil lebih percaya diri dalam menghadapi berbagai situasi (Montana, 2001 dalam Respati dkk., 2006). Konsep diri yang positif juga berhubungan erat dengan dengan harga diri yang tinggi dan persepsi akan makna dalam hidup yang positif (Crocetti, E. \& Van Dijk, 2016).

Berdasarkan pembahasan di atas yang menjelaskan bahwa perkembangan konsep diri yang positif pada remaja akan sangat menentukan keberfungsian dalam relasi sosialnya, maka kondisi lingkungan keluarga menjadi faktor utama agar remaja dapat mengembangkan konsep diri yang adekuat. Keluarga yang utuh, dengan relasi yang hangat antara orang tua dan anak, akan membantu tercapainya optimalisasi perkembangan konsep diri yang positif pada remaja (Ellison dkk., 2011). Namun, pada kenyataannya, fenomena perceraian tidak dapat terhindarkan dan dapat dialami oleh siapa saja. Orgilés dkk., (2012) dan Hamama \& Ronen-Shenhav (2012) dalam penelitiannya, menggarisbawahi dampak negatif perceraian terhadap perkembangan konsep diri remaja, yang tentu saja akan sangat mempengaruhi munculnya berbagai perilaku negatif, seperti ketidakpuasan akan bentuk tubuh, gangguan makan, masalah internalisasi perilaku, motivasi belajar, dan pergaulan yang buruk. Oleh karena itu, penelitian ini perlu dilakukan untuk mengkaji terkait konsep diri remaja yang memiliki orang tua bercerai.

Lebih lanjut, penelitian ini juga akan memfokuskan kepada faktor usia anak ketika perceraian terjadi dikarenakan peneliti menemukan bahwa faktor usia anak masih belum banyak digali dalam penelitian- 
penelitian sebelumnya. Terdapat penelitian terdahulu yang dilakukan Morrison, dkk. (2017) membahas mengenai bagaimana pengalaman remaja dengan perceraian orang tua mereka berpengaruh pada beberapa aspek perilaku remaja seperti komunikasi terbuka versus tertutup (avoidant), pandangan remaja tentang diri mereka sendiri, dan pandangan mereka tentang hubungan di masa depan (baik kekeluargaan maupun romantis).

Lalu, lebih lanjut dijelaskan bahwa keterbatasan dalam penelitian ini adalah mayoritas partisipan sudah berusia remaja ketika perceraian orang tua terjadi. Morrison dkk. (2017) menjelaskan bahwa usia dan tahun perkembangan partisipan ketika perceraian terjadi bisa memberikan pengaruh terhadap diri remaja. Sebab individu yang mengalami perceraian orang tua pada usia yang berbeda dapat memberikan respon yang berbeda. Terdapat pula penelitian milik Uphold-Carrier \& Utz (2012), meskipun penelitian ini berfokus pada depresi remaja yang mengalami perceraian orang tua, namun peneliti tertarik pada dua dimensi waktu yang digunakan, yaitu time since divorce yang menilai berapa lama waktu telah berlalu sejak perceraian, dan age at parental divorce, yaitu usia di mana seseorang mengalami perceraian orang tua. Hasil penelitian ini menyebutkan bahwa variabel age at parental divorce memiliki pengaruh terhadap depresi remaja yang mengalami perceraian orang tua. Dapat diketahui bahwa usia anak ketika perceraian terjadi menjadi satu aspek yang penting pada perilaku anak. Oleh karena itu, peneliti memutuskan untuk menjadikan faktor usia anak ketika perceraian terjadi untuk melihat bagaimana konsep diri remaja dipengaruhi oleh perceraian orang tua.

Berdasarkan keterbatasan dalam penelitian Morisson dkk. (2017) dan juga kurangnya penelitian yang membandingkan usia remaja ketika perceraian orang tua terjadi, maka peneliti berusaha mengelaborasi keterbatasan penelitian tersebut dengan cara melibatkan partisipan remaja yang memiliki orang tua bercerai dan mengalami peristiwa perceraian orang tua tersebut saat menginjak usia yang berbedabeda satu dengan yang lain.

\section{Desain Penelitian}

\section{METODE}

Penelitian ini menggunakan desain penelitian kualitatif. Penelitian kualitatif adalah penelitian yang bermaksud untuk memahami fenomena tentang apa yang dialami oleh subyek penelitian misalnya perilaku, persepsi, motivasi, tindakan, dan lain-lain dengan cara deskripsi dalam bentuk kata-kata, pada suatu konteks khusus yang alamiah dengan memanfaatkan berbagai metode ilmiah (Moleong, 2017). Penelitian ini menggunakan pendekatan studi kasus. Studi kasus adalah tipe pendekatan dalam penelitian kualitatif yang berfokus terhadap satu kasus dan dilakukan secara intensif, mendalam, mendetail, serta komprehensif (Jailani, 2013). Penelitian ini menggunakan pendekatan studi kasus instrumental. Pendekatan ini digunakan ketika kasus yang diteliti dapat digunakan untuk memperbaiki atau menyempurnakan konstruk teori yang telah ada (Stake, 2005). Peneliti memilih pendekatan ini guna menyempurnakan teori milik Fitts (1971, dalam Agustiani, 2009) yang kurang menunjukkan secara detail adanya interaksi antar dua dimensi yang membangun konstruk konsep diri yaitu dimensi internal dan dimensi eksternal.

\section{Partisipan}

Karakteristik partisipan pada penelitian ini adalah remaja wanita atau pria yang berusia antara 11-24 tahun, serta mengalami fenomena perceraian orang tua saat masa kanak-kanak ataupun masa remaja. Sebelum berpartisipasi dalam penelitian, seluruh partisipan telah menandatangani perjanjian dalam informed consent. Didapatkan empat partisipan yang terbagi ke dalam dua kelompok yaitu JA dan PF 
yang mengalami perceraian orang tua saat usia kanak-kanak, sedangkan AP dan RA adalah partisipan yang mengalami perceraian orang tua saat telah berusia remaja. JA, AP dan RA berusiai 22 tahun, sementara PF berusia 19 tahun. Setelah perceraian orang tua JA, PF dan AP tinggal bersama ibunya, sementara RA tinggal bersama neneknya.

\section{Strategi Pengumpulan Data}

Peneliti menyiapkan pedoman wawancara yang telah disusun sesuai dengan teori konsep diri milik Fitts yang membagi kedalam dua dimensi yaitu internal dan eksternal yang kemudian terbagi lagi dalam beberapa subdimensi. Dimensi internal terbagi dalam tiga subdimensi yaitu diri identitas, diri pelaku dan diri penilai. Dimensi eksternal terbagi ke dalam lima subdimensi yaitu diri fisik, diri etik-moral, diri pribadi, diri keluarga dan diri sosial. Adanya pedoman wawancara digunakan untuk memudahkan proses dalam pelaksanaan penggalian data agar jalannya wawancara dapat lebih terarah namun tetap terbuka pada kemungkinan untuk melakukan eksplorasi atau probing terhadap jawaban yang diberikan oleh partisipan

\section{HASIL PENELITIAN}

\section{a. Partisipan JA}

Perceraian orang tua terjadi ketika JA berusia delapan tahun, terdapat latar belakang konflik KDRT pada keluarga JA sebelum orang tuanya bercerai. JA memiliki diri identitas yaitu egois, keras kepala, ambisius, dan juga gengsi untuk mengakui kesalahannya. Ia memiliki sifat egois karena setelah bercerai ia hanya tinggal bersama ibunya, ia juga menilai tidak pernah mendapat nasihat dari orang tuanya. Diri pelaku JA yaitu ia sulit untuk mendengarkan nasihat maupun teguran dari orang lain, ia juga sering kali membanting barang seperti pintu kamar. Selain itu ia juga memiliki perilaku destruktif menonton pornografi sejak masih anak-anak. JA memiliki kepuasan dan harga diri yang rendah.

Pasca perceraian orang tuanya, JA menilai kesehatan fisiknya buruk. Hal ini karena keadaan ekonomi ibu JA tidak stabil saat itu. Ia juga memandang keadaan dan penampilan fisiknya kurang dan tidak menarik. Lalu JA memiliki nilai untuk selalu membantu sesama terutama yang sedang kesusahan, nilai ini ia dapatkan dengan melihat role model orang tuanya. JA menilai bahwa pemaknaannya terhadap Tuhan tidak membantunya dalam mengatasi permasalahan perceraian orang tua. Saat orang tuanya belum bercerai, JA merasa takut, cemas dan panik. Hal ini disebabkan konflik KDRT dalam keluarganya. Kemudian ketika orang tuanya akan bercerai hingga pasca perceraian, ia merasa bahagia dan lebih tenang. JA menilai dirinya tidak memiliki peran dan kedudukan yang penting sebagai anak di dalam keluarga. Ketika masih anak-anak, JA tidak terlalu melakukan interaksi dengan teman sebayanya. Walau demikian, seiring berjalannya waktu, ia mulai membuka diri dalam pertemanan.

\section{b. Partisipan PF}

Perceraian orang tua PF terjadi ketika ia berusia dua tahun. Setelah orang tuanya bercerai, PF tinggal bersama eyangnya, namun ketika kelas empat SD ia pindah untuk tinggal bersama ibu dan ayah tirinya. Saat masih anak-anak PF memiliki diri identitas yang mudah marah akan sesuatu yang tidak ia sukai. Semakin beranjak remaja ia memiliki sifat dan karakter yang egois. Lalu, PF memiliki diri pelaku yaitu perilaku destruktif yaitu menyakiti diri sendiri dengan cara membenturkan kepala pada tembok ketika masih anak-anak. Semakin beranjak remaja tepatnya SMP, ia kembali melakukan perilaku menyakiti diri seperti menyayat anggota tubuhnya menggunakan cutter. Pada diri penilai, PF memiliki kepuasan dan harga diri yang rendah. 
Diri fisik PF yaitu ia tidak begitu memiliki masalah pada kesehatan fisiknya, namun perilaku menyakiti diri yang ia lakukan membuat tubuhnya memiliki luka. PF memandang keadaan dan penampilan fisiknya cukup dan tidak merasa kurang. PF memiliki diri etik-moral yaitu nilai moral untuk selalu berbuat baik pada orang lain, nilai ini kemudian membantunya mengatasi konflik dalam keluarganya, yaitu tuntutan dalam hal akademik yang PF terima dari orang tuanya. Ia tetap akan patuh dan taat pada orang tuanya meskipun di sisi lain ia tidak suka pada tuntutan dari orang tuanya tersebut. PF juga menilai pemaknaan akan Tuhan yang ia miliki membantunya mengatasi masalah akibat perceraian orang tua. PF memiliki dinamika diri pribadi yaitu ia merasa biasa aja dan tidak sedih ketika mulai menyadari bahwa orang tuanya bercerai ketika ia SD. Saat itu PF tengah merasa bahagia karena tinggal bersama eyangnya dan dimanjakan oleh eyangnya. Namun ketika kelas empat SD, ia harus pindah untuk tinggal bersama ibu dan ayah tirinya, saat itu ia merasa kesal dan marah karena terdapat perbedaan pola asuh antara ibu dan eyangnya. Beranjak remaja PF juga merasa tidak disayang dan diperhatikan oleh orang tuanya. PF tidak pernah menilai dirinya memiliki peran serta kedudukan yang penting di dalam keluarga hingga saat ini. Ketika masih berusia anak-anak, PF tidak terlalu banyak melakukan interaksi dengan teman-teman sebayanya. Saat ini walaupun PF tetap tidak sering untuk berinteraksi dengan teman sebayanya, namun PF dapat lebih membuka dirinya dalam pertemanan.

\section{c. Partisipan AP}

Orang tua AP bercerai ketika ia berusia remaja, yaitu 18 tahun. Setelah perceraian tersebut, ia tinggal bersama ibu dan adiknya. Sebelum orang tuanya bercerai, AP menilai diri identitasnya yang digambarkan melalui sifat dan karakter yaitu tidak terlalu peduli pada apa yang orang lain rasakan atau pikirkan. Kemudian setelah perceraian, ia menjadi individu yang lebih terbuka dan lebih empati pada orang lain. Setelah perceraian AP juga memiliki diri pelaku yang lebih positif yaitu berperilaku empati. Namun di sisi lain ia juga memiliki perilaku destruktif dan agresif seperti membanting barang dan cenderung membentak ketika berbicara dengan orang lain. AP memiliki diri penilai yaitu kepuasan diri yang rendah.

AP menilai kesehatan maupun penampilan fisiknya cenderung menjadi lebih baik ketika orang tuanya telah bercerai. AP tidak memiliki nilai-nilai moral dari orang tuanya yang dapat ia bawa untuk menjadi pedomannya pada masa remaja. AP menilai ketika orang tuanya belum bercerai, ia merasa takut, cemas, dan tidak nyaman. Lalu ketika orang tuanya memutuskan untuk bercerai hingga saat ini, ia merasa lebih tenang dan damai. Setelah orang tuannya bercerai, ia menilai dirinya memiliki kedudukan dan peran yang penting di dalam keluarga bahkan ia melihat dirinya sebagai kepala keluarga menggantikan ayahnya. AP menilai interkasi dengan teman-teman sebayanya merupakan support system yang sangat membantunya dalam mengatasi permasalahan perceraian orang tuanya.

\section{d. Partisipan RA}

Orang tua RA bercerai ketika ia telah remaja yaitu saat berusia 14 tahun. Sebelum bercerai, orang tuanya jarang menunjukkan pertengkaran di hadapan RA. Setelah bercerai ibu RA pindah ke luar kota sehingga ia tinggal bersama ayahnya. Namun hal tersebut hanya bertahan selama satu tahun karena ayahnya pun pindah ke rumah orang tuanya. Sejak saat itu ia hanya tinggal bersama eyangnya, namun eyangnya pun tidak selalu pulang ke rumah RA karena memiliki rumah yang lain. Sebelum orang tuanya bercerai, RA menilai diri identitasnya yaitu egois dan tidak peduli pada orang lain. Lalu ketika orang tuanya telah bercerai ia menjadi lebih empati pada orang lain, ia juga merasa untuk tidak selalu harus sempurna. Diri pelakunya pun menjadi lebih berperilaku empati pada orang-orang disekitarnya. RA memiliki diri penilai yaitu ia tidak puas terhadap dirinya, tetapi di sisi lain, saat ini RA telah mampu menerima diri dan keadaannya termasuk perceraian orang tuanya. 
RA memandang keadaan dan penampilan fisiknya saat ini cukup dan tidak kurang. RA menilai, pasca perceraian orang tuanya ia sempat mengalami sakit akibat kekurang nutrisi pada makanan yang ia konsumsi. RA memiliki nilai untuk selalu berbuat baik dan kebaikannya tersebut akan kembali padanya, namun nilai ini tidak RA dapatkan dari orang tuanya. Menurut RA nilai ini sangat membantunya mengatasi masalah akibat perceraian orang tua. Sebelum orang tuanya bercerai, ia cenderung merasa sedih dan kasihan ketika orang tuanya harus bertengkar. Setelah perceraian orang tuanya, RA menilai dirinya tidak lagi memiliki kedudukan serta peran yang penting dalam keluarga. RA menilai interaksi dirinya dengan teman sebayanya sangat membantu dirinya dalam mengatasi masalah akibat perceraian orang tua. contohnya seperti saat RA belum mencuci seragam sekolah maka temannya akan meminjamkannya.

\section{DISKUSI}

\section{a. Dinamika Konsep Diri Remaja yang Mengalami Perceraian Orang Tua Ketika Usia Anak-Anak (JA dan PF)}

Diri identitas keduanya setelah perceraian orang tua cenderung negatif yaitu memiliki sifat egois. Hal ini karena perceraian terjadi pada usia perkembangan seorang anak, dimana orang tua memegang peranan yang sangat penting. Diri identitas kedua partisipan mempengaruhi diri pelaku yaitu sifat egois JA membuatnya menjadi tidak dapat mendengarkan nasihat orang lain. Sementara sifat egois PF membuatnya memiliki perilaku tidak dapat berbagi dengan orang lain. Setelah perceraian kedua orang tua, kedua partisipan sama-sama memiliki perilaku destruktif. Hal ini sesuai dengan yang dikatakan oleh Kelly \& Emery (2003), bahwa anak-anak yang memiliki orang tua bercerai lebih memungkinkan untuk memiliki masalah perilaku. Perilaku destruktif keduanya disebabkan oleh diri pribadi dan juga diri keluarga. Keduanya merasa tidak diperhatikan dan juga perasaan-perasaan lainnya yang dijelaskan dalam diri pribadi. JA dan PF juga menilai bahwa mereka tidak memiliki kedudukan yang penting sebagai anak bagi orang tuanya. Lalu dengan mengevaluasi diri pelaku mereka, yaitu perilaku destruktif, keduanya menilai bahwa diri penilai mereka yaitu kepuasan dan harga diri mereka rendah.

Kedua subyek memiliki proses diri pribadi yang berbeda, hal ini disebabkan oleh support system dan konflik dalam masing-masing keluarga yang juga berbeda. JA memiliki latar belakang konflik KDRT sebelum orang tuanya bercerai sehingga yang ia rasakan adalah takut dan cemas. Hal ini dapat dijelaskan bahwa anak-anak sering merespons konflik orang tua dengan emosi yang negatif seperti ketakutan, kecemasan, dan stres (Ellison dkk., 2011). Sementara PF memiliki konflik keluarga yang lebih minim. Namun setelah bercerai, keduanya sama-sama merasa tidak dipedulikan oleh orang tuanya, perasaan inilah yang membuat JA dan PF memiliki diri pelaku yang negatif yaitu perilaku destruktif. Lalu setelah perceraian orang tua, keduanya merasa tidak memiliki kedudukan yang penting dalam keluarga. Hal ini karena saat itu ibu JA sangat sibuk bekerja dan tidak memiliki waktu bersamanya, sementara komunikasi JA dengan ayahnya saat itu sangat minim karena hubungan yang tidak harmonis.

PF sendiri menilai orang tuanya tidak pernah memperhatikan apa yang menjadi keinginannya dan tidak pernah menanyakan pendapatnya dalam setiap keputusan yang diambil. Hal ini juga yang mendong JA dan PF dalam diri pelaku yang negatif. Ketidakhadiran figur orang tua juga mempengaruhi diri identitas JA yaitu ia menjadi egois. Diri sosial keduanya saat usia anak-anak dipengaruhi oleh diri pelaku. Perilaku menonton pornografi yang dilakukan JA menghambatnya dalam berinteraksi dengan teman sebayanya. JA tidak tahu harus membicarakan apa ketika berinteraksi dengan teman sebayanya. Sementara PF lebih fokus pada dunianya sendiri yaitu sebuah idol group. Anak-anak cenderung berteman dengan teman sebaya yang mempunyai kesamaan dengannya. Kesamaan ini disebut sebagai homofili, yaitu 
kecenderungan untuk bergaul dengan orang lain yang serupa (Brechwald \& Prinstein, 2011 dalam Santrock, 2014). Interaksi keduanya juga dipengaruhi oleh diri penilai yaitu mereka tidak yakin bahwa teman-temannya dapat membuat mereka bahagia. Namun seiring berjalannya waktu, keduanya semakin membuka diri dalam pertemanan.

\section{b. Dinamika Konsep Diri Remaja yang Mengalami Perceraian Orang Tua Ketika Usia Remaja (AP dan RA)}

Diri identitas kedua partisipan setelah perceraian orang tua yaitu sifat dan karakter empati kepada orang lain mempengaruhi diri pelaku keduanya, yaitu AP dan RA semakin berperilaku empati atau pada perasaan orang lain. AP menjadi lebih terbuka pada latar belakang dari perilaku orang lain, diri identitasnya ini kemudian mempengaruhi diri pribadinya yaitu ia tidak mudah merasa kecewa terhadap perilaku orang lain. Sementara diri identitas dan diri pelaku RA ini dipengaruhi oleh diri penilainya yaitu ia semakin memiliki kesadaran diri bahwa apa yang ia lakukan dulu tidaklah baik. Lalu diri penilai keduanya yaitu kepuasan diri yang rendah dipengaruhi oleh diri pelaku dan diri keluarga. JA merasa tidak puas karena ia masih memiliki perilaku yang negatif, sementara RA merasa tidak puas karena ia belum memiliki peran penting dalam keluarga yaitu belum mampu membantu orang tuanya secara finansial.

Diri fisik AP dipengaruhi oleh diri sosialnya, yaitu ia lebih memperhatkan penampilan fisiknya karena ia ingin menunjukkan pada lingkungan sosialnya bahwa perceraian tidak lantas membuat penampilannya menjadi buruk. Selain itu setelah perceraian kesehatan fisik AP juga semakin baik, hal ini dipengaruhi oleh diri pribadinya. AP tidak lagi merasa takut maupun cemas sehingga tidak perlu melampiaskannya dengan makan pada waktu yang tidak tepat seperti saat dini hari. Hal ini disebut emotional eating, yaitu makan sebagai respons terhadap isyarat emosional, dan seringkali sebagai respons untuk mengatasi emosi negatif (Bennett dkk., 2013). Sementara diri fisik RA yaitu penampilan dipengaruhi oleh diri identitasnnya. RA tidak lagi merasa harus selalu sempurna, sehingga ia menilai penampilannya cukup. Sementara kesehatan fisik RA pasca perceraian orang tua dipengaruhi oleh support system yaitu ia tidak lagi memiliki orang tua yang dapat memperhatikan kesehatannya seperti saat sebelum bercerai. Diri pribadi keduanya dipengaruhi oleh konflik dan support system keluarga yang berbeda satu sama lain. Kedua partisipan sepakat bahwa diri sosial mereka yaitu interaksi dengan teman sebaya sangat membantu mereka dalam mengatasi permasalahan perceraian orang tua terutama pada diri pribadi yaitu perasaan-perasaan yang mereka rasakan.

\section{SIMPULAN}

Diri identitas kedua partisipan yang mengalami perceraian orang tua saat usia anak-anak cenderung negatif, sementara partisipan yang mengalami perceraian orang tua di usia remaja cenderung positif. Diri identitas keempat partisipan dari dua kelompok usia sama-sama mempengaruhi diri pelaku mereka. Diri pribadi partisipan yang mengalami perceraian orang tua saat usia anak-anak juga mempengaruhi diri pelaku keduanya yaitu memiliki perilaku destruktif. Selain itu diri keluarga JA dan RA yaitu penilaian bahwa mereka tidak memiliki kedudukan yang penting bagi orang tuanya turut mempengaruhi diri pelaku keduanya. Sementara diri pribadi pada partisipan yang mengalami perceraian orang tua saat usia remaja mempengaruhi diri sosial mereka yaitu keduanya menghabiskan lebih banyak waktu untuk berinteraksi dengan teman-teman sebayanya.

Dapat disimpulkan juga bahwa usia anak ketika perceraian orang tua terjadi tidak sepenuhnya mempengaruhi aspek-aspek pada konsep diri remaja. Melainkan juga cenderung dipengaruhi oleh support system seperti orang tua dan teman sebaya, keadaan ekonomi, dan juga konflik pada masing- 
masing keluarga. Selain itu, tantangan dalam pembentukan konsep diri menjadi lebih menantang pada kelompok yang mengalami perceraian orang tua saat anak-anak, karena mereka mengalami proses yang lebih panjang dan perceraian terjadi pada masa kritis perkembangan seorang anak.

Orang tua diharapkan dapat memberi dukungan pada anak-anaknya dengan bentuk perhatian dan kasih sayang terutama pada pasca perceraian sehingga anak tidak merasa kehilangan sosok orang tua. Lalu penelitian selanjutnya disarankan agar mengklasifikasikan latar belakang dari perceraian yang mungkin nantinya dapat membedakan konsep diri pada anak.

\section{UCAPAN TERIMAKASIH}

Terima kasih kepada orang tua, saudara, teman-teman, dan partisipan yaitu JA, PF, AP dan RA serta dosen-dosen Fakultas Psikologi UNAIR. Penelitian ini dapat berjalan dengan lancar karena adanya dukungan kalian kepada peneliti.

\section{DEKLARASI POTENSI TERJADINYA KONFLIK KEPENTINGAN}

Ni Luh Ayu W. S. K. dan Aryani Tri Wrastari tidak bekerja, menjadi konsultan, memiliki saham, atau menerima dana dari perusahaan atau organisasi manapun yang mungkin akan mengambil untung dari diterbitkannya naskah ini.

\section{PUSTAKA ACUAN}

Agustiani, H. (2009). Psikologi Perkembangan (Pendekatan Ekologi Kaitannya dengan Konsep Diri dan Penyesuaian Diri pada Remaja) (D. Pakar (ed.)). PT Refika Aditama.

Amato, P. R. (1994). Life-span adjustment of children to their parents' divorce. The Future of children / Center for the Future of Children, the David and Lucile Packard Foundation, 4(1), 143-164.

Bennett, J., Greene, G., \& Schwartz-Barcott, D. (2013). Perceptions of emotional eating behavior. A qualitative study of college students. Appetite, 60(1), 187-192.

Crocetti E., Van Dijk M.P. (2016) Self-Concept Clarity. In: Levesque R. (eds) Encyclopedia of Adolescence. Springer, Cham. https://doi.org/10.1007/978-3-319-32132-5_808-2.

Dusek, J. B., Flaherty, J. F., \& Hill, J. P. (1981). The Development of the Self-Concept during the Adolescent Years. Monographs of the Society for Research in Child Development, 46(4), 1-67.

Ellison, C. G., Walker, A. B., Glenn, N. D., \& Marquardt, E. (2011). The effects of parental marital discord and divorce on the religious and spiritual lives of young adults. Social Science Research, 40(2),

Gunarsa, S. D. \& Gunarsa, Y. S. (2008). Psikologi Perkembangan Anak dan Remaja. PT BPK Gunung Mulia. 
Hamama, L., \& Ronen-Shenhav, A. (2012). Self-control, social support, and aggression among adolescents in divorced and two-parent families. Children and Youth Services Review, 34(5), 10421049.

Jailani, M. S. (2013). Ragam Penelitian Qualitative. Edu-Bio, 41-49.

Jayani, D. H. (2019). Ramai RUU Ketahanan Keluarga, Berapa Angka Perceraian di Indonesia? / Databoks. https://databoks.katadata.co.id/datapublish/2020/02/20/ramai-ruu-ketahanan-keluargaberapa-angka-perceraian-di-indonesia

Kaur, J., Rana, J. S., \& Kaur, R. (2009). Home Environment and Academic Achievement as Correlates of Self-concept among Adolescents. Studies on Home and Community Science, 3(1), 13-17.

Kelly, J. B., \& Emery, R. E. (2003). Children's Adjustment Following Divorce: Risk and Resilience Perspectives. Family Relations, 52, 352-362.

Moleong, L. J. (2017). METODOLOGI PENELITIAN KUALITATIF. PT REMAJA ROSDAKARYA.

Morrison, S. C., Fife, S. T., \& Hertlein, K. M. (2017). Mechanisms behind Prolonged Effects of Parental Divorce: A Phenomenological Study. Journal of Divorce and Remarriage, 58(1), 44-63.

Orgilés, M., Méndez, X., Spence, S. H., Huedo-Medina, T. B., \& Espada, J. P. (2012). Spanish validation of the spence children's anxiety scale. Child Psychiatry and Human Development, 43(2), 271-281.

Respati, W. S., Yulianto, A., \& Widiana, N. (2006). Perbedaan konsep diri antara remaja akhir yang mempersepsi pola asuh orang tua authoritarian, permissive, dan authoritative. Jurnal Psikologi, $4(2), 119-138$.

Santrock, J. W. (2014). Child Development (Fourth Ed.). McGraw-Hill Education.

Stake, R. E. (2005). Qualitative Case Studies. In N. K. Denzin \& Y. S. Lincoln (Eds.), The Sage handbook of qualitative research (pp. 443-466). Sage Publications Ltd.

Turner, H. A., Finkelhor, D., \& Ormrod, R. (2010). The effects of adolescent victimization on self-concept and depressive symptoms. Child Maltreatment, 15(1), 76-90.

Uphold-Carrier, H., \& Utz, R. (2012). Parental Divorce Among Young and Adult Children: A Long-Term Quantitative Analysis of Mental Health and Family Solidarity. Journal of Divorce and Remarriage, 53(4), 247-266. 